\title{
EFFECT OF BACILLUS CEREUS ON DEVELOPMENT OF MIGRATORY LOCUST, LOCUSTA MIGRATORIA (R\&F)
}

\author{
V.D. Raut ${ }^{1}$, M. Sen ${ }^{2}$ and M.M. Rai ${ }^{2}$ \\ ${ }^{1}$ Department of Zoology, Tai Golwalkar Science College, Ramtek, Dist. Nagpur (M.S.) \\ ${ }^{2}$ Centre for Sericulture and Biological Pest Management Research (CSBR), \\ RTM Nagpur University, Nagpur-440022, India \\ E-Mail: vijayraut14@yahoo.co.in, manoj_ngp@ rediffmail.com
}

\begin{abstract}
Migratory locust, Locusta migratoria (Acrididae: Orthoptera) is a serious oligophagous pest of agriculture, found mostly in African, Asian and Australian continents. A bacterium isolated from eggs of L. migratoria was identified as Bacillus cereus CSBRLE2. The pathogenic effects of B. cereus on development and various tissues and haemolymph protein in L. migratoria have been investigated. Third instar nymphs were starved and inoculated with $10 \mathrm{il}$ of bacterial suspension having concentration of $8 \times 10^{8} \mathrm{cfu} / \mathrm{ml}$. The individuals were maintained in the laboratory up to adult maturation and egg laying. Body weight of the B. cereus inoculated individuals significantly reduced as compared to control. High mortality and lower fecundity and hatching percentage observed in the groups inoculated with bacterium. Inoculation of bacteria reduced the total haemolymph protein in adults as compared to control. The present study demonstrates that B. cereus could be used against $L$. migratoria in combination with other viable agents to help in management of locust and grasshoppers population in the field.
\end{abstract}

KEYWORDS: Bacillus cereus, Locusta migratoria, migratory locust.

\section{INTRODUCTION}

Locusts are the swarming phase of short-horned grasshoppers belong to family Acrididae in the order Orthoptera. The desert locust, Schistocerca gregaria and migratory locust, Locusta migratoria are the two main swarming species of economic importance. These two species infest about 29 million sq. $\mathrm{km}$. of area covering 57 countries in Asia, and Africa ${ }^{5}$ In India, the locust are mostly found in western part of Gujarat and Rajasthan. L. migratoria is a recognized global pest that feeds on a wide range of graminaceous crops and pasture.

Currently the integrated pest management strategy has been tried for the locust and grasshopper control. Biocontrol agents belonging to the group's protozoa, bacteria, fungus and virus are the most important pathogens and have been tried on large scale st,10,13. $^{2}$

The bacteria found in the gut are mostly symbiotic in nature and confined to gut. Even though the members disclose symbiotic relationships with appropriate invertebrate hosts, however occasionally enter a pathogenic life cycle in which the individual species infect suitable hosts and multiplies almost unrestrained ${ }^{8}$. $B$. thuringiensis is regarded as an insect pathogen commonly used as a crop protection agent against insects from the orders of Lepidoptera, Diptera and Coleoptera $^{10,16}$. The ecology of $B$. thuringiensis is still an enigma: it is a ubiquitous soil microorganism, but it can also be found in other environmental niches, 
including phylloplane and the insect host intestinal system, rarely causing natural epizootic episodes ${ }^{8}$. On the other hand $B$. anthracis and $B$. cereus spores are found in the soil. B. cereus can be occasionally found in the insect gut not only as spores but also as growing vegetative cells 6,11 . The alimentary canal of $L$. migratoria harbor a variety of microorganisms, mainly bacteria ingested along with food which further transmitted into haemolymph.

The Bacillus cereus group is a very homogeneous cluster within the Bacillus genus, comprised of six recognized species; B. cereus, B. thuringiensis, B. anthracis, $B$. mycoides, $B$. pseudomycoides and $B$. weihenstephanensis. In 1887, a bacterium Bacillus cereus was isolated from air in a cowshed $^{4}$. B. cereus is a large, $1 \times 3-4 \mu \mathrm{m}$, Gram-positive, rod-shaped, endospore forming, facultative aerobic bacterium. The B. cereus group has recently been discovered as common inhabitants of the invertebrate gut. B. cereus is also a contributor to the micro flora of insects, deriving nutrients from its host. Thus $B$. cereus isolated from the 2 days old eggs of locust, L. migratoria and its pathogenecity was tested against the migratory locust, L. migratoria.

\section{MATERIALS AND METHODS}

\section{Rearing of locust}

The migratory locusts were reared at insectaries at the Centre for Sericulture and Biological Pest Management Research (CSBR) under controlled condition in wooden cage having dimension 18 x 18 x
24 inch $(\mathrm{LxWxH})$.

\section{Preparation of Inoculum}

The pure culture of $B$. cereus isolated from locusts eggs was maintained at CSBR. The inoculums of $B$. cereus having concentration of $8 \times 10^{8} \mathrm{CFU} / \mathrm{ml}$ was prepared from the stock with the help of Mc. Farland turbidity test.

\section{Inoculation}

Newly moulted third instars male and female of L. migratoria were separated and starved in plastic bowl covered with lid perforated small hole for 12-14 hrs. Before inoculation weight of individuals were recorded. The $10 \mu \mathrm{l}$ inoculum smeared on pieces $\left(1 \mathrm{~cm}^{2}\right)$ of Sorghum leaves, allowed to air dry and fed to numphs individually and the group is labeled as treated/ inoculated group. Similarly pieces $\left(1 \mathrm{~cm}^{2}\right)$ of Sorghum leaves smeared with sterile nutrient broth were given to the nymphs and used as a control. After inoculation, the insect were placed in rearing cage and served regular feed of fresh Sorghum leaves twice a day. Various parameters during development of experimental individuals such as weight, duration of development, mortality, fecundity and hatching and total protein in the haemolymph of developing stages and the F1 eggs were recorded and compared.

\section{RESULTS AND DISCUSSION}

The migratory locust $L$. migratoria was reared and maintained in the laboratory at Center for sericulture and Biological Pest 
management Research (CSBR) and observed the developmental changes at nymph and adult stages in the cage under laboratory condition.

Effect of B. cereous on body weight during nymphal development was observed from the fourth instar and similar trend observed recorded in late fifth instar, however at the adult stage the initial weight was not significantly different but as the adult reached maturation stage the body weight significantly reduced in the inoculated individuals (Table 1).

Table-1. Effect of B. cereus on body weight of L. migratoria

\begin{tabular}{|l|c|c|c|c|c|c|}
\hline S.NO. & STAGES & & \multicolumn{2}{|c|}{ CONTROL (weight in g) } & \multicolumn{2}{c|}{ INOCULATED (weight in g) } \\
\hline & & & Initial & Final & Initial & Final \\
\hline \multirow{2}{*}{1} & III & M & $0.081 \pm 0.004$ & $0.121 \pm 0.002$ & $0.069 \pm 0.001$ & $0.098 \pm 0.014$ \\
\cline { 3 - 7 } & & F & $0.102 \pm 0.018$ & $0.173 \pm 0.000$ & $0.085 \pm 0.008$ & $0.145 \pm 0.017$ \\
\hline 2 & \multirow{2}{*}{ IV } & M & $0.123 \pm 0.008$ & $0.303 \pm 0.031$ & $0.117 \pm 0.041$ & 0.2200 .031 \\
\cline { 3 - 7 } & & F & $0.219 \pm 0.072$ & $0.344 \pm 0.018$ & $0.214 \pm 0.053$ & $0.344 \pm 0.022$ \\
\hline \multirow{3}{*}{3} & V & M & $0.704 \pm 0.049$ & $0.715 \pm 0.068$ & $0.510 \pm 0.071$ & $0.563 \pm 0.081$ \\
\cline { 3 - 7 } & & F & $0.783 \pm 0.066$ & $0.946 \pm 0.273$ & $0.620 \pm 0.114$ & $0.771 \pm 0.134$ \\
\hline \multirow{3}{*}{ Adult } & M & $0.882 \pm 0.017$ & $1.025 \pm 0.028$ & $0.815 \pm 0.026$ & $0.857 \pm 0.066$ \\
\cline { 3 - 7 } & & F & $1.182 \pm 0.003$ & $1.806 \pm 0.054$ & $1.019 \pm 0.359$ & $1.377 \pm 0.761$ \\
\hline
\end{tabular}

The effect of $B$. cereus on mortality was also evidenced right from the third instar and by late fifth instar stage the mortality was significantly high in the inoculated groups and reached $31.8 \%$ compared to $6.8 \%$ in control. During adult stage the mortality obtained was $22.7 \%$ compared to $2.2 \%$ in control. The total mortality including nymph and adult was $54.5 \%$ in inoculated group compared to $9.0 \%$ in control suggest the pathogenic effect of B. cereus on L. migratoria (Table 2).

In haemolymph during fifth instar slight reduction in the total protein was observed. Protein level reduced significantly during early stage on $10^{\text {th }}$ day to $97.4 \mathrm{mg} / \mathrm{ml}$ compared to $116.0 \mathrm{mg} / \mathrm{ml}$ in control. This reduction narrowed down and the difference reduced at the late adult stage on $20^{\text {th }}$ day after oviposition (Table 3).

The amount of protein in eggs laid by females of control and inoculated varied significantly. On day 4 the amount of protein in the egg was $0.77 \mathrm{mg} / \mathrm{egg}$ whereas in inoculated group it was $0.55 \mathrm{mg} / \mathrm{egg}$. The level of protein reduced drastically on $10^{\text {th }}$ day to $0.18 \mathrm{mg} / \mathrm{egg}$ compared to $0.32 \mathrm{mg} / \mathrm{egg}$ 
Table: 2. Effect of B. cereus on mortality of L. migratoria

\begin{tabular}{|c|c|c|c|c|c|c|c|c|}
\hline Group & Insect & \multicolumn{7}{|c|}{ Mortality } \\
\hline & Tested & \multicolumn{3}{|c|}{ Nymph } & \multicolumn{4}{|c|}{ Adult } \\
\hline & & IIIrd & IV & $\mathbf{V}$ & Adult & Total & $\begin{array}{c}\text { Nymph } \\
(\%)\end{array}$ & $\begin{array}{c}\text { Adult } \\
(\%)\end{array}$ \\
\hline Control & 44 & - & 1 & 2 & 1 & 4 & 6.8 & 2.2 \\
\hline Inoculated & 44 & 3 & 4 & 7 & 10 & 24 & 31.8 & 22.7 \\
\hline
\end{tabular}

Table-3. Effect of B. cereus on total haemolymph protein of L. migratoria

\begin{tabular}{|l|c|c|c|}
\hline STAGES & DAY & CONTROL $(\mathbf{m g} / \mathbf{m l})$ & INOCULATED $(\mathbf{m g} / \mathbf{m l})$ \\
\hline V & Late stage & 4.05 & 3.72 \\
\hline Adult & 10 Early & 116 & 97.4 \\
\hline Adult & 20 Late & 90.06 & 74.10 \\
\hline
\end{tabular}

in control and later the protein level slightly control (Table 4). reduced in inoculated whereas increased in

Table- 4. Effect of B. cereus on total protein in the eggs of L. migratoria

\begin{tabular}{|l|c|c|c|}
\hline Test & Day & Control (mg/egg) & Inoculated (mg/egg) \\
\hline 1. & 4 & 0.74 & 0.55 \\
\hline 2. & 10 & 0.32 & 0.18 \\
\hline 3. & 14 & 0.34 & 0.13 \\
\hline
\end{tabular}

The mated female of control group laid 38 eggs/pod compared to 26eggs/pod by the females of $B$. cereus inoculated. The female of control group laid average 4.2 pods/ female, whereas females of $B$. cereus inoculated group laid 2 pods/female. The total number of eggs laid by 10 female was 1615 compared to 520 in $B$. cereus inoculated and reduction was $32.2 \%$. Similarly hatching also significantly reduced $65.38 \%$ in $B$. cereus inoculated group compared to $92.13 \%$ in control (Table 5).

In the present study, bacteria isolated from eggs belong to Bacillus group pathogenic to insect. The structural characteristics of inoculated locust individuals were altogether different than control. Another member of the insecticidal toxin producing species of the genus Bacillus is the soil-occurring B. sphaericus, which is part of the $B$. subtilis group 6 . B. 
Table- 5. Effect of B. cereus on fecundity and hatching percentage of L. migratoria

\begin{tabular}{|l|c|c|c|c|c|c|c|}
\hline Group & $\begin{array}{c}\text { Number } \\
\text { of } \\
\text { Female }\end{array}$ & $\begin{array}{c}\text { Number } \\
\text { of } \\
\text { egg pod }\end{array}$ & $\begin{array}{c}\text { Number } \\
\text { of } \\
\text { eggs/pod }\end{array}$ & $\begin{array}{c}\text { Average } \\
\text { Egg pods/ } \\
\text { female }\end{array}$ & $\begin{array}{c}\text { Total } \\
\text { Eggs } \\
\text { (No. })\end{array}$ & $\begin{array}{c}\text { Hatched } \\
\text { Nymphs }\end{array}$ & $\begin{array}{r}\text { Hatching } \\
\text { percent }\end{array}$ \\
\hline Control & 10 & 42.5 & 38 & 4.2 & 1615 & 1488 & 92.13 \\
\hline Inoculated & 10 & 20 & 26 & 2 & 520 & 340 & 65.38 \\
\hline
\end{tabular}

sphaericus is toxic against mosquito larvae. The mosquitocidal properties are due to the action of two types of toxins, the highly active binary toxins $\mathrm{Bin} A / \mathrm{BinB}$ within spore crystals and the Mtx toxins ${ }^{3}$. Upon ingestion 220 M. Sanchez-Contreras and I. Vlisi dou by the target insect, the binary toxins are solublized and proteo-lytically activated, bind specific receptors and form pores in target cells disrupting the mosquito gut epithelium $^{1,2}$. The Mtx1/2/3 families of toxins are produced during vegetative growth and their low activity might be due to low levels of production in addition to degradation during sporulation. Interestingly, purified Mtx1 showed very high toxicity against mosquito larvae ${ }^{17}$. Mtx proteins can act synergistically with other mosquitocidal toxins ${ }^{18}$.

In the present study B. cereous isolated from the eggs of L. migratoria also showed pathogenic effect, lead to reduction in the body weight increased maturation time may be due to insecticidal activity as reported earlier where $B$. thuringiensis strain showed insecticidal activity against Mediterranean locust, D. maroccanus ${ }^{12}$. B. thuringiensis is a spore-forming bacterium showing the unusual ability to produce endogenous crystals during sporulation that are toxic for some pest insects. The different protein profiles of spore-crystal mixtures by sulfatepolyacrylamide gel electrophoresis isolates out of which three isolates active against locusts ${ }^{12}$.

Toxicity test against L. migratoria manilensis, demonstrated that trypsin-treated sporulated cultures and crystal proteins had high toxicity to larval and adult locusts. Cry toxin of BTH-13 was detected on the midgut of treated locusts using immune-fluorescent technology, which confirmed the site of action of the crystal proteins in their toxicity for locusts 16 .

It was evidenced from the above study that amount of haemolymph protein reduced during nymphal and early adult stages when inoculated with $B$. cereus and at later stages after post maturation and oviposition concentration of haemolymph protein was not significantly changed. The reduction might be due to recovery in the individual's immunity system and the insect survived during later stage of development. Similarly the egg protein was also significantly reduced in inoculated compared to control. Due to lack of egg protein the embryonic development suppressed and eggs were 
incompetent and unable to hatch thus hatching percentage was reduced.

From the present study it can be postulated that the use of $B$. cereous could be useful in controlling locust population if applied at an early stage of development in combination with other microorganism and semio-chemicals.

\section{ACKNOWLEDGEMENTS}

The authors are thankful to Dr. M. K. Rathod and Dr. S. M. Wazalwar for their technical support and Mr. Gopal Sayam for his assistance during locust rearing and experiments.

\section{REFERENCES}

1. Darboux, I., C. Nielsen-LeRoux, J.F. Charles and D. Pauron, 2001. The receptor of Bacillus sphaericus binary toxin in Culex pipiens (Diptera: Culicidae) midgut: molecular cloning and expression. Insect Biochem Mol Biol., 31, 981-90.

2. Davidson, S.K., S.W Allen., G.E Lim, C.M. Anderson and M.G. Haygood, 2001. Evidence for the biosynthesis of bryostatins by the bacterial symbiont 'Candidatus Endobugula sertula' of the bryozoan Bugula neritina. Appl. Environ. Microbiol., 67: 45314537.

3. de Maagd, R.A., M. Weemen-Hendriks, J.W. Molthoff and S. Naimov, 2003. Activity of wild-type and hybrid Bacillus thuringiensis delta-endotoxins against Agrotis ipsilon. Arch Microbiol., 179: 363-7.

4. Frankland G.C. and P.F. Frankland, 1887. Studies on new microorganisms from air. Philosophical transactions of the Royal Society of London. Series B, Biological Sciences 173: 257-287.

5. Ferenz, H.J., 1990. Locust pheromones- basic and applied aspects. Bol. San. Veg. Plagas Fuera de serie., 20: 29-37.

6. Helgason, E., O.A. Okstad, D.A. Caugant, H.A. Johansen, A. Fouet, M. Mock, I. Hegna and A.B. Kolsto, 2000. Bacillus anthracis, Bacillus cereus, and Bacillus thuringiensisone species on the basis of genetic evidence. Appl Environ Microbiol., 66: 2627-30.

7. Hu, X., W. Fan, B. Han, H. Liu, D. Zheng, Q. Li, W. Dong, J. Yan, M. Gao and C. Berry, 2008. Complete genome sequence of the mosquitocidal bacterium Bacillus sphaericus C3-41 and comparison with closely related Bacillus species. J Bacteriol.

8. Jensen, G.B., B.M. Hansen, J. Eilenberg and J. Mahillon, 2003. The hidden lifestyles of Bacillus cereus and relatives. Environ. Microbiol., 5: 631-40.

9. Lecadet, M.M., E. Frachon, V.C. Dumanoir, H. Ripouteau, S. Hamon, P Laurent and I. Thiery, 1999. Updating the H-antigen classification of Bacillus thuringiensis. J Appl Microbiol., 86: 660-72.

10. Lomer, C.J. and C. Prior, 1991. Biological control of locusts and Grasshoppers - In "Proceedings of a workshop held at the International Institute of Tropical Agricultural, Cotonou, Republic of Benin, 29 April-1 May.

11. Margulis, L., J.Z. Jorgensen, S. Dolan, R. Kolchinsky, F.A. Rainey and S.C. Lo, 1998. The Arthromitus stage of Bacillus cereus: intestinal symbionts of animals. Proc Natl Acad Sci U S A, 95: 1236-41.

12. Quesada-Moraga, E. and C. Santiago-Alvarez, 2001. Rearing and breeding of the Moroccan locust Dociostaurus maroccanus (Thunberg) (Orthop., Acrididae) under laboratory conditions. J. Appl. Entomol., 125: 121-124.

13. Rai, M.M., S.K. Raina and A.M. Khurad, 2002. Field trials of Nosema locustae for control of paddy grasshopper, Hieroglyphus spp. in Vidarbha of India. Entomon. 28(3): 207-214.

14. Raina, S.K., M.M. Rai and A.M. Khurad, 1987. Third and Final technical report (phase-I) 
Biological Pest Management Project. (IDRC, Canada). Nagpur University, Nagpur. pp. 1-130.

15. Schnepf, E., N. Crickmore, J. Van Rie, D. Lereclus, J. Baum, J. Feitelson, D.R. Zeigler and D.H. Dean, 1998. Bacillus thuringiensis and its pesticidal crystal proteins. Microbiol. Mol. Biol. Rev., 62: 775-806.

16. Song L., M. Gao, S. Dai, Y. Wu, D. Yi and R. Li, 2008. Specific activity of a Bacillus thuringiensis strain against Locusta migratoria manilensis. J. Invertebr. Pathol., 98:169-176.
17. Thanabalu, T. and A.G. Porter, 1995. Efficient expression of a 100-kilodalton mosquitocidal toxin in protease-deficient recombinant Bacillus sphaericus. Appl Environ. Microbiol., 61: 4031-6.

18. Wirth, M.C., Y. Yang, W.E. Walton, B.A. Federici and C. Berry, 2007. Mtx toxins synergize Bacillus sphaericus and Cry11Aa against susceptible and insecticide resistant Culex quinquefasciatus larvae. Appl Environ. Microbiol., 73: 6066-71. 